\title{
STORED WATER QUALITY IN HOUSEHOLD ROOF TANKS OF VILLAS IN SELECTED AREAS OF SHARJAH, UNITED ARAB EMIRATES
}

\author{
LUCY SEMERJIAN*, HANAN OBAID \& HUDA ZAROUNI \\ Department of Environmental Health Sciences, College of Health Sciences, University of Sharjah, UAE
}

\begin{abstract}
Water quality control is crucial throughout its supply, distribution, and storage to safeguard consumers and mitigate the spread of water associated diseases. The aim of the current study is to comprehensively assess water quality in private villa household water storage tanks in random areas of Sharjah, United Arab Emirates. The study explores the variation in physico-chemical, as well as microbiological, water quality parameters, the factors contributing to the quality of stored water, as well as the most common water tank cleaning practices by the owners. Forty-four water samples were collected from water storage tanks, and analyzed for a variety of water quality parameters. Results demonstrate that overall physico-chemical quality of stored water is acceptable except for operational parameters such as electrical conductivity and chlorides in 50\% of investigated samples; yet, such parameters do not pose major health hazards. However, residual chlorine levels were below minimum requirements set by water quality authorities in $93 \%$ of the samples, which may pose a risk of water re-contamination. The microbiological quality was satisfactory in terms of total coliforms yet total bacterial counts and occasional presence of fungi and molds suggest poor hygienic conditions and highlight the need for tank cleaning. Household water tank owners rarely clean their tanks thus it is highly recommended to promote such measures and educate tank owners about the importance of regular tank cleaning and maintenance.
\end{abstract}

Keywords: water quality assessment, water storage tanks, water guidelines, United Arab Emirates.

\section{INTRODUCTION}

Water-related diseases are considered to be a major cause of global morbidity and mortality as more than 3.4 million people die annually from such diseases, and most of the sufferers are children [1]. Absent, inadequate, or inappropriately managed water and sanitation services expose individuals to preventable health risks. Thus, safe drinking water is a necessity and it can be achieved only if it is well controlled throughout all its phases of supply, distribution, storage, and end use.

Various researchers studied previously water quality in water storage tanks and highlighted the importance of tank cleaning and maintenance. In Nyankpala, Ghana, 120 water samples were collected and analyzed from different types of water storage tanks. Generally, the physico-chemical quality of stored water was good since parameters measured well with World Health Organization (WHO) recommended limits. However, color, turbidity, and total iron levels recorded in stored water in metallic containers were higher than WHO drinking water guidelines. Also, stored water analyzed from all types of storage facilities recorded coliform bacteria, probably resulting from unhygienic waterhandling practices as such containers were rarely cleaned and were unprotected from faecal contamination. Water stored in earthen pots recorded the lowest level of coliform bacteria (total coliform (TC) 0-315 CFU/100 mL, faecal coliform (FC) 0-78 CFU/100 mL) while

*ORCID: http://orcid.org/0000-0002-6683-2075 
water stored in polyethylene tanks recorded highest levels of coliform bacteria (TC 0-714 CFU/100 mL, FC 0-250 CFU/100 mL) [2].

Another water quality study of household storage tanks was conducted in Tiquipaya, Bolivia. No significant difference in physical and chemical water quality between polyethylene, fiberglass and cement water storage tanks were noted but there was a difference in microbial $E$. Coli contamination $(\mathrm{p}=0.082)$. This was possibly linked to the black color of polyethylene tanks which increased water temperatures to $33.7^{\circ} \mathrm{C}$ compared to temperatures ranging between $20-23^{\circ} \mathrm{C}$ for other tanks. Also, tank age was found not altering water quality; however, cleaning frequency may have contributions to microbial water quality [3].

Several sources of water from household storage tanks were also investigated in Gaza Strip. The presence of biological contamination was detectable in $75.7 \%$ of water storage tanks. With reference to chemical investigations, $\mathrm{pH}$ was mostly below the acceptable level, with values ranging from 4.4 to 6.3 [4]. Furthermore, 100 water samples were collected and analyzed for major anions, cations, and heavy metals to assess the effect of the residential storage tanks on the quality of drinking water in Al-Karak Province, Jordan. Results showed higher ionic concentrations in comparison to source waters which could be due to the hot and dusty summers in the region. Increased levels of heavy metals were also found in the drinking water [5]. A study conducted in the unincorporated neighborhoods in El Paso County, Texas revealed low chlorine levels and high bacteriological contamination in drinking water storage tanks due to the improper maintenance measures. The study encouraged educating such communities about proper storage of drinking water as well as about the risks of unsafe water use [6]. Another study was conducted by Sule et al. [7] to assess the physiochemical and bacteriological quality of household water storage tanks in Ilorin, Nigeria. As the sources for each water storage tank were different (municipal water, wells, borehole) the results varied as well. For instance, $\mathrm{pH}$ readings varied from 6.53 to 7.45 , and many bacterial counts were positive showing different species, including E. coli and Pseudomonas aeruginosa, while, only $40 \%$ of the samples had suspended solid readings within the limits according to WHO standards.

In the United Arab Emirates (UAE), municipalities assure that the water produced and distributed to consumers is subject to continuous monitoring and is always safe, and regulate as well as highlight the importance of water storage tanks proper installation, maintenance and cleaning. However, a good quality potable drinking water may be subject to recontamination by not following the Municipality regulations for water storage and water tanks cleaning. The responsibility to keep the water up to the standard lies with all the residents, landlords and property owners [8].

In this regard, studies conducted and published in UAE related to household water storage tanks and water quality seem very limited. In a single preliminary study conducted by Amiri et al. [9], water samples collected from eleven houses from both ground and roof level water storage tanks were assessed for microbial quality however, physico-chemical analysis was not considered in the study. The study revealed that $54.5 \%$ of the samples were positive for coliforms; yet, none of the samples were contaminated by E. coli. Total bacterial count (TBC) results revealed that eight out of the eleven sampled houses exceeded acceptable TBC standards.

The main aim of the current research study is to comprehensively assess the water quality in household water storage tanks related to stand-alone villas in random areas of Sharjah, UAE. The study explores the variation in physico-chemical as well as microbiological water quality parameters, the factors contributing to the quality of stored water as well as the most common water tank cleaning practices by the owners. Such a 
study may serve as a measure to promote the importance of cleaning and proper maintenance of storage tanks at the household level as well as increase the confidence of the consumers towards the quality of stored water.

\section{MATERIALS AND METHODOLOGY}

\subsection{Sample and data collection}

Twenty two household water storage tanks of stand-alone villas were randomly selected throughout Sharjah City and suburbs, and the tanks were sampled in duplicates in two sampling rounds. The first sampling round was conducted in the Fall season, while the second round was completed in Winter. A custom-designed water sampler and sterile $250 \mathrm{ml}$ glass bottles were used to collect water samples properly from depths at middle of tanks to avoid any possible cross-contamination. Collected water samples were cooled to $4^{\circ} \mathrm{C}$ and transported to the University of Sharjah (UoS) laboratories within allowable holding times to be analyzed for a series of physico-chemical and microbiological parameters.

At time of sample collection, a questionnaire was distributed to the house owners to collect necessary information related to the specifications of the tanks (age, dimension, material, presence of cover, etc.), use of stored water, as well as tank maintenance and cleaning measures. Additionally, field observations related to the tank status and surroundings were recorded.

\subsection{Analytical procedures}

Collected samples were analyzed on-site for water temperature. At the University water lab, samples were analyzed for the parameters listed in Table 1, which also specifies the adopted analytical reference methods [10].

Table 1: Analytical parameters and reference methods.

\begin{tabular}{|c|c|c|}
\hline Parameter & Method principle & Reference method \\
\hline pH (@o25C) & Electrometric & SM 4500-H+ \\
\hline Electrical conductivity (uS/cm @ 25ㄷ) & Electrochemical & SM 2510 B \\
\hline Total hardness $\left(\mathrm{mg} / \mathrm{L}\right.$ as $\left.\mathrm{CaCO}_{3}\right)$ & Titrimetric & SM $2340 \mathrm{C}$ \\
\hline Turbidity (NTU) & Nephelometry & SM $2130 \mathrm{~B}$ \\
\hline Sulfates $\left(\mathrm{mg} / \mathrm{L} \mathrm{SO}_{4}{ }^{2-}\right)$ & Turbidimetric & HACH 8051 \\
\hline Nitrates $\left(\mathrm{mg} / \mathrm{L} \mathrm{NO}_{3}-\mathrm{N}\right)$ & Colorimetric & HACH 8039 \\
\hline Phosphates (mg/L PO4 $\left.4^{3-}\right)$ & Colorimetric & НАCH 8048 \\
\hline Chlorides (mg/L) & Titrimetric & SM 4500-Cl-B \\
\hline Free and total chlorine $(\mathrm{mg} / \mathrm{L})$ & Colorimetric & $\mathrm{HACH} 8021$ and 8167 \\
\hline Metals - Fe, $\mathrm{Cu}, \mathrm{Pb}(\mathrm{mg} / \mathrm{L})$ & ICP-OES & SM 3120 B \\
\hline Total coliforms (CFU/ml) & $\begin{array}{l}\text { Membrane filtration } \\
\text { (M Endo agar) }\end{array}$ & SM 9221 B-C \\
\hline Molds and fungi (CFU/ml) & $\begin{array}{l}\text { Membrane filtration } \\
\text { Spread plate culture }\end{array}$ & SM 9610 C-D \\
\hline $\begin{array}{l}\text { Heterotrophic plate counts, HPC } \\
(\mathrm{CFU} / \mathrm{ml})\end{array}$ & $\begin{array}{l}\text { Membrane filtration } \\
\text { Spread plate culture }\end{array}$ & SM 9215 C-D \\
\hline
\end{tabular}




\section{RESULTS AND DISCUSSION}

Surveys and observations revealed that $90 \%$ of investigated tanks were polyethylene plastic while the remaining were glass fiber reinforced plastic (GRP). Water storage tanks' age varied from 2 months to more than 10 years, and they were either located at the ground level or on villa roofs. All investigated water tanks were covered except a single tank. Volumes of tanks varied from 400 till 1200 gallons to fulfill various types of activities and purposes. Owners expressed that they rarely clean their tanks and stored water is used for various domestic activities, such as washing, cooking, cleaning, and irrigation. Table 2 summarizes recorded averages of analyzed physico-chemical water quality parameters. Average results for samples collected during the Fall season are tabulated as A whereas B relates to average results recorded in the Winter season.

As for microbiological parameters, all samples exhibited $0 \mathrm{CFU} / 100 \mathrm{ml}$ for total coliforms, four samples yielded positive results for molds and yeasts with counts ranging between 4-23 CFU/100 ml, and as for HPC all samples yielded counts exceeding $100 \mathrm{CFU} / 100 \mathrm{ml}$. Although, total bacterial counts do not impose serious health hazards to consumers; however, they are an indicator of poor hygienic practices. Water temperature ranged between 28 to $34^{\circ} \mathrm{C}$ in the Fall season, and from 17 to $26^{\circ} \mathrm{C}$ in Winter season.

Sharjah households receive their drinking water from three main sources provided by Sharjah Electricity and Water Authority (SEWA), namely desalinated seawater from various desalination plants, water from wells, and desalinated water from Abu Dhabi distribution company. The multiple sources of water cause a variation in the water quality parameters. $84 \%$ of $\mathrm{pH}$ readings varied from 8.02 to 8.90 units, and all recorded $\mathrm{pH}$ values were within minimum and maximum guideline values set by WHO, GSO (GCC Standardization Organization), or WQR (Water Quality Regulations) as shown in Fig. 1(a) [11]-[13]. As for electrical conductivity, GSO and WQR set a minimum level of 100 and a maximum level of $1,000 \mathrm{uS} / \mathrm{cm}$ at $25^{\circ} \mathrm{C}$. None of the samples' conductivity dropped below $100 \mathrm{uS} / \mathrm{cm}$ at $25^{\circ} \mathrm{C}$ however approximately $50 \%$ of investigated water samples exceeded the recommended maximum limit (Fig. 1(b)). This was also linked to higher chloride levels in samples, especially in Fall sampling round (Fig. 1(c)). No major health implications are associated with drinking water with high electrical conductivity or chloride but such parameters are typically controlled to avoid corrosion and to reduce salty taste of water. Two samples (19 and 20) had a significant variation between the two rounds in terms of conductivity and chloride levels as salt removing units were installed in the second round. For turbidity, 7\% of the results were over WHO maximum limits. As for hardness, its occurrence in water systems is related to groundwater sources, since as water moves through geological formations it dissolves small amounts of minerals [14]. In the geographical area under study, most of the water supplies are desalination plants which remove hardness. Fig. 1(d) shows that hardness results were below the GSO and WQR acceptable level of 200-300 mg/L as $\mathrm{CaCO}_{3}$ in 18 samples out of 22 in fall season and in all winter season results. However, WHO sets a recommended level of $100-300 \mathrm{mg} / \mathrm{L}$ as $\mathrm{CaCO}_{3}$, thus $77 \%$ of fall results and $68 \%$ of winter results ranged between the limit. As for nitrates and sulfates, all recorded average results were within WHO, GSO, and WQR acceptable levels (Fig. 1(e) and (f)). Phosphate results ranged from 0.01 to $3.19 \mathrm{mg} / \mathrm{L}$.

Chlorine is a well-known disinfectant used in water treatment and maintaining a residual in distributed and stored water in approved amounts assures safe water. Water provided by SEWA is chlorinated and distributed to consumers with a free residual chlorine concentration ranging between 0.2 and $1.0 \mathrm{mg} / \mathrm{L}$. However, recorded results showed very low free and total chlorine levels in the collected water samples, mostly below minimum 


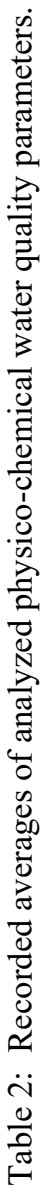

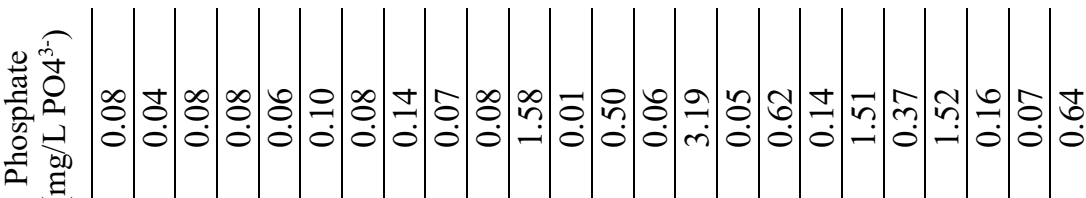

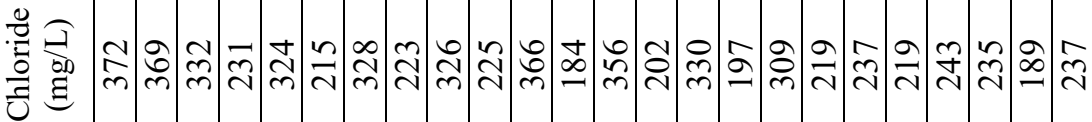

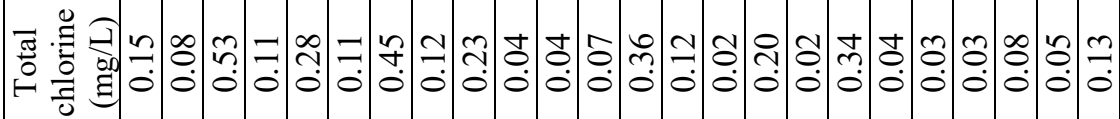
党 Z

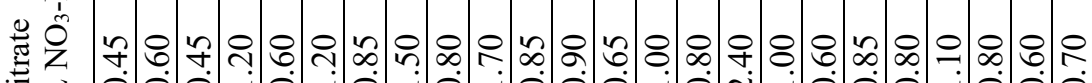

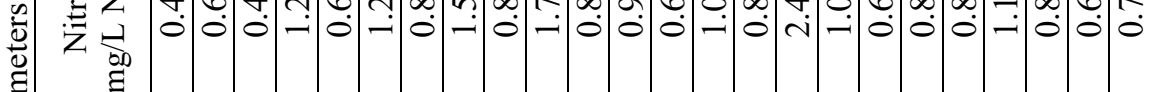
$\Xi$

(ึ)

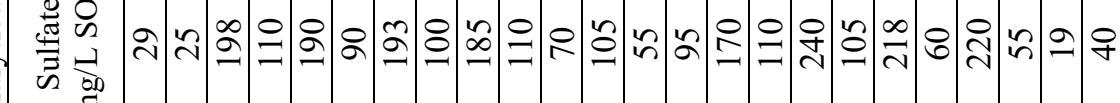
娄

氕

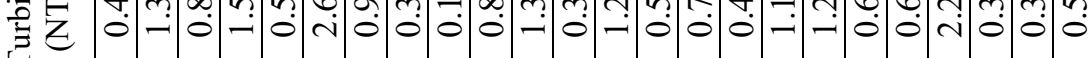

胥

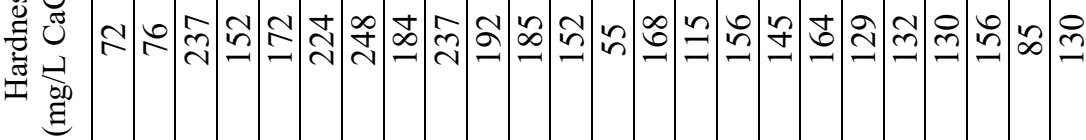

릉

总 过 $\frac{0}{\Xi}$

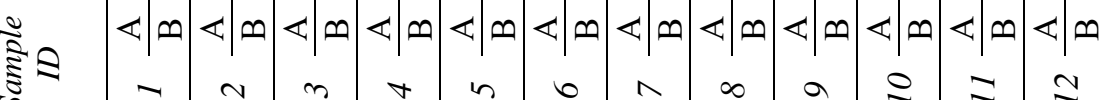

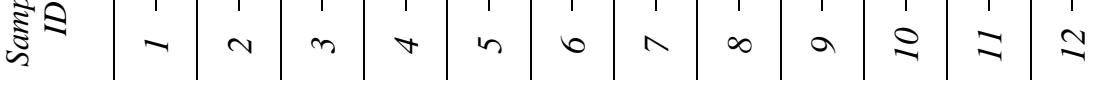




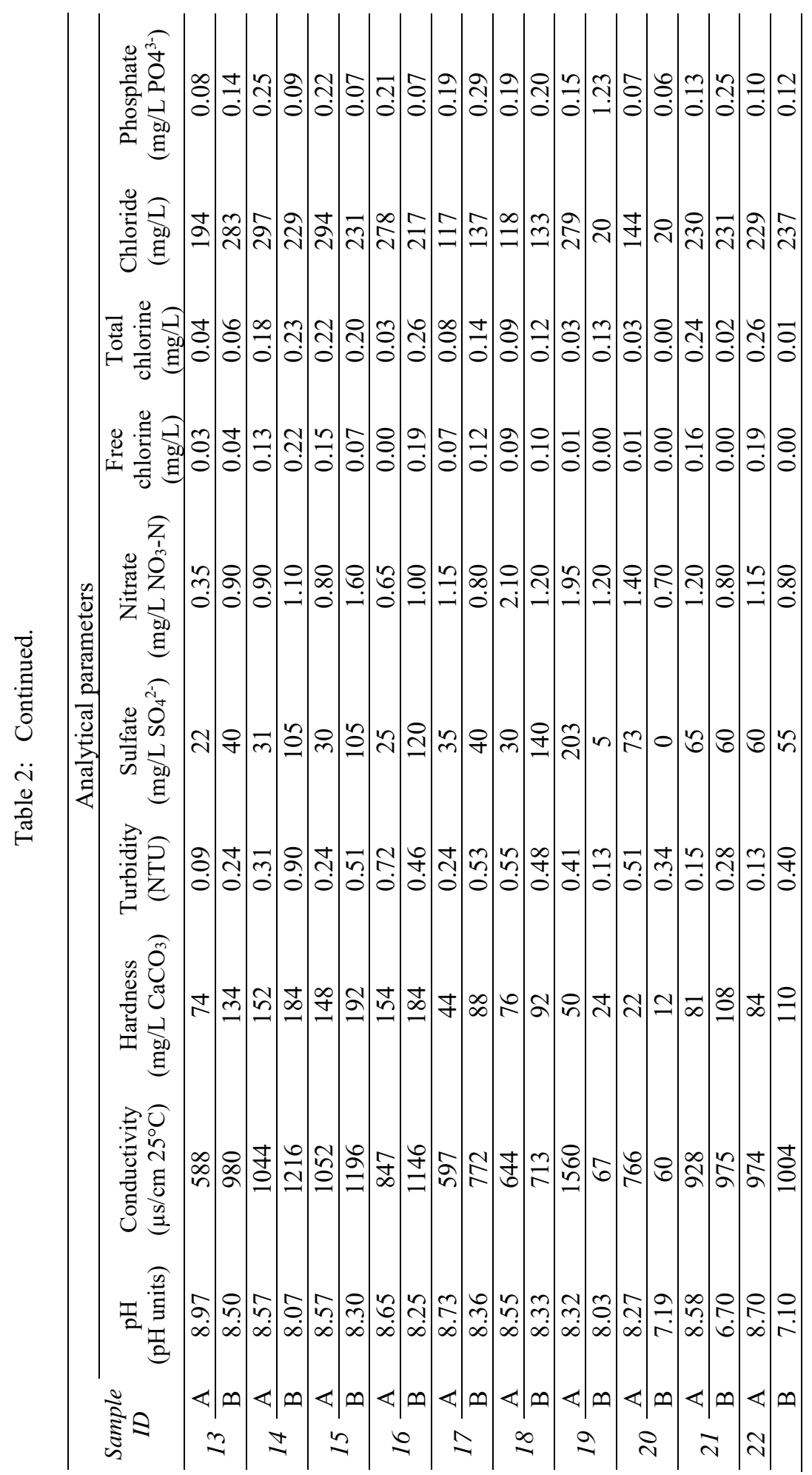




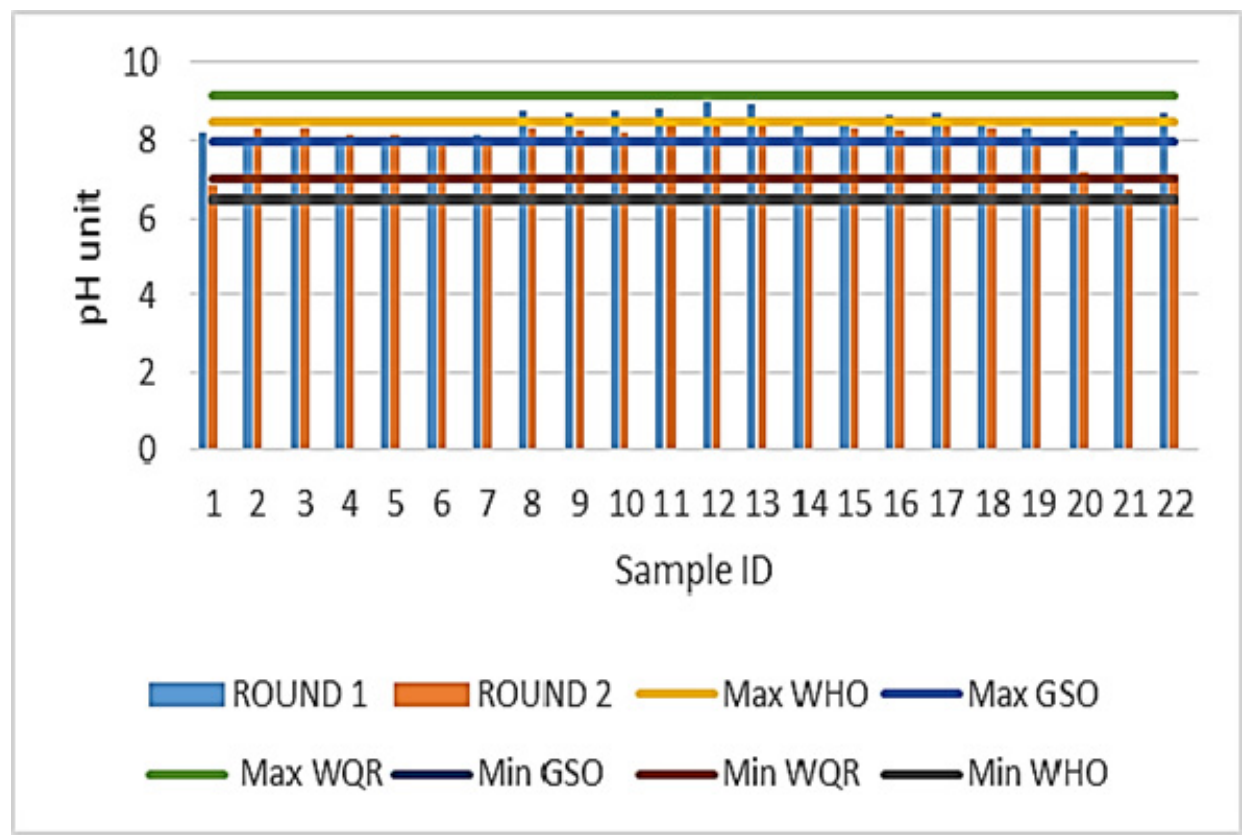

(a)

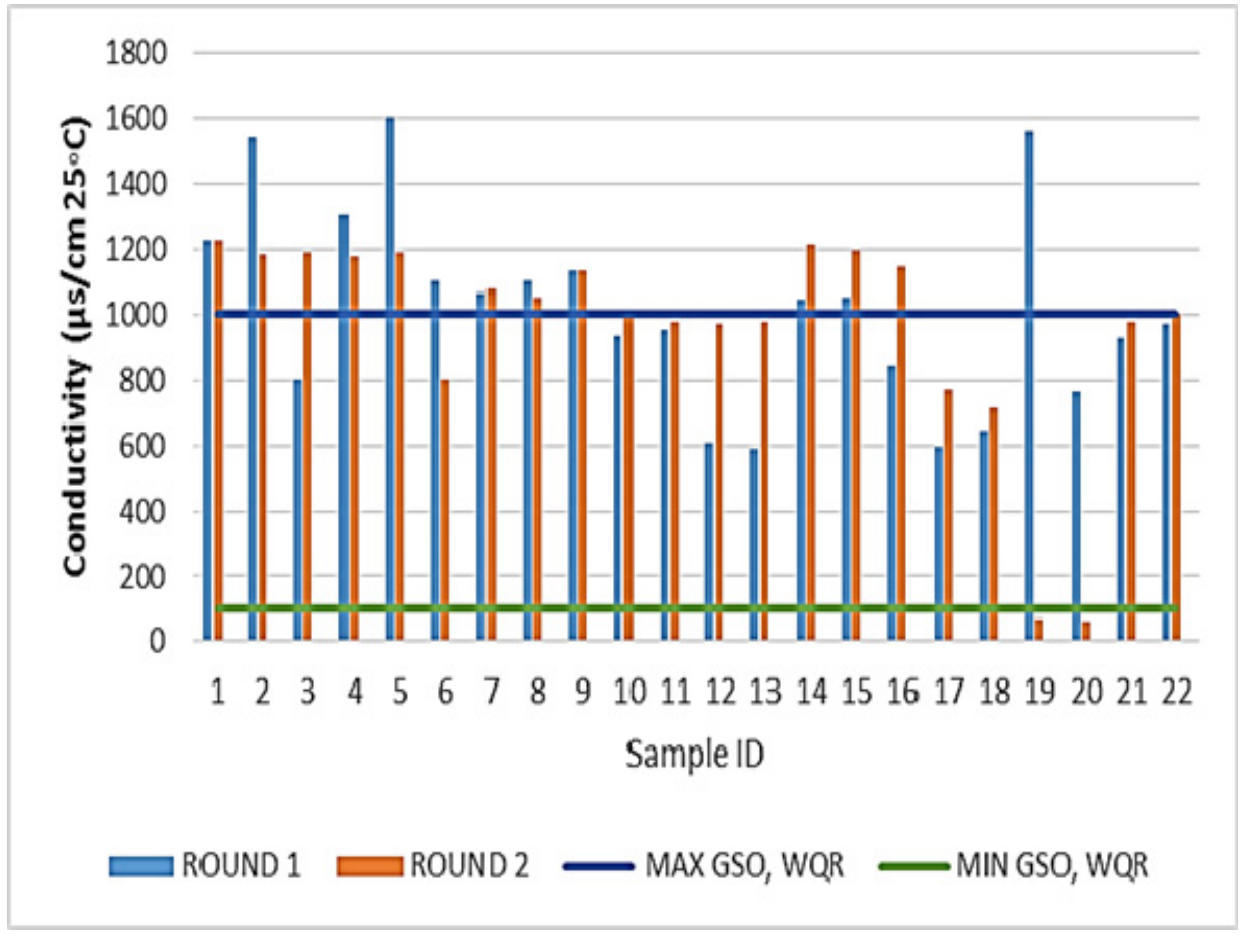

(b)

Figure 1: Physico-chemical water parameters compared to GSO, WHO, and WQR drinking water guidelines. 


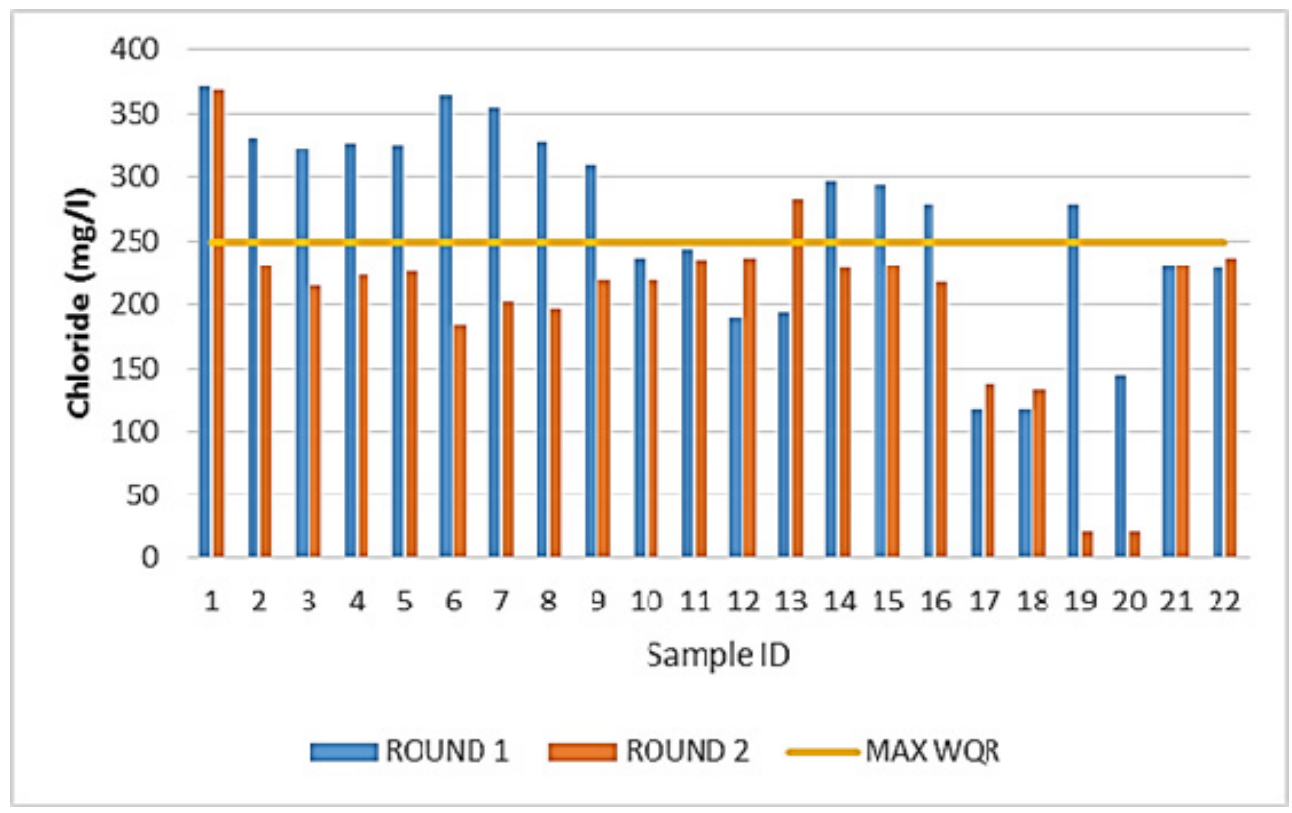

(c)

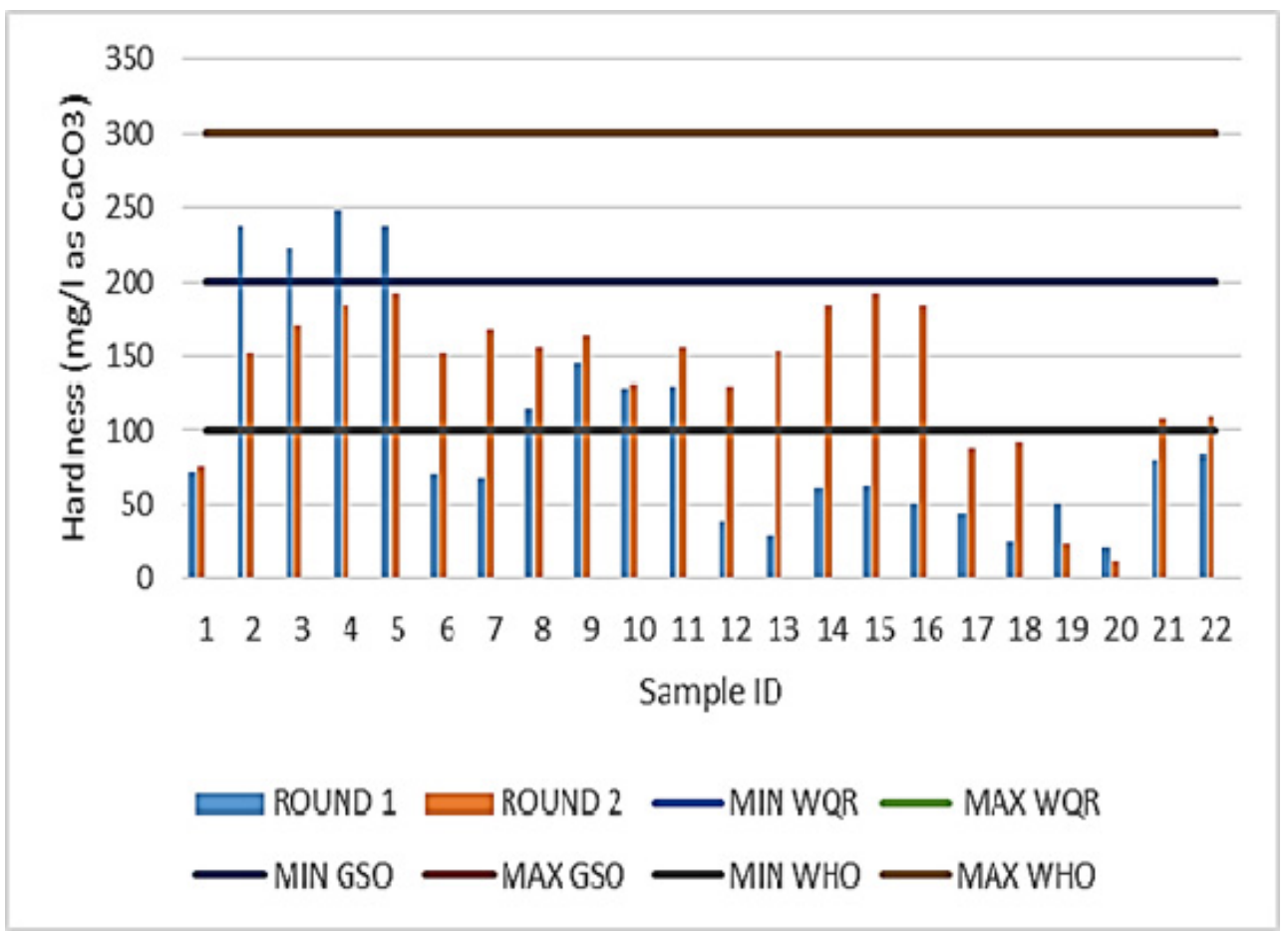

(d)

Figure 1: Continued. 


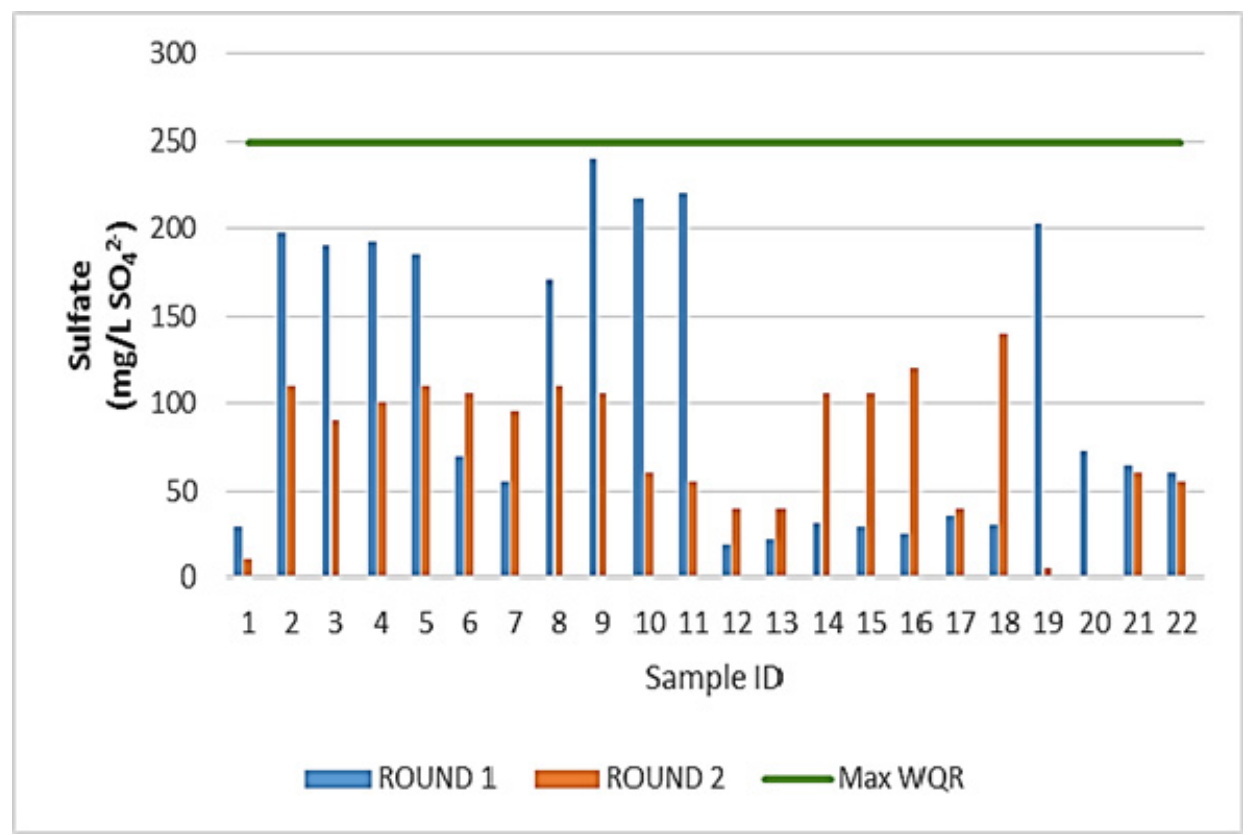

(e)

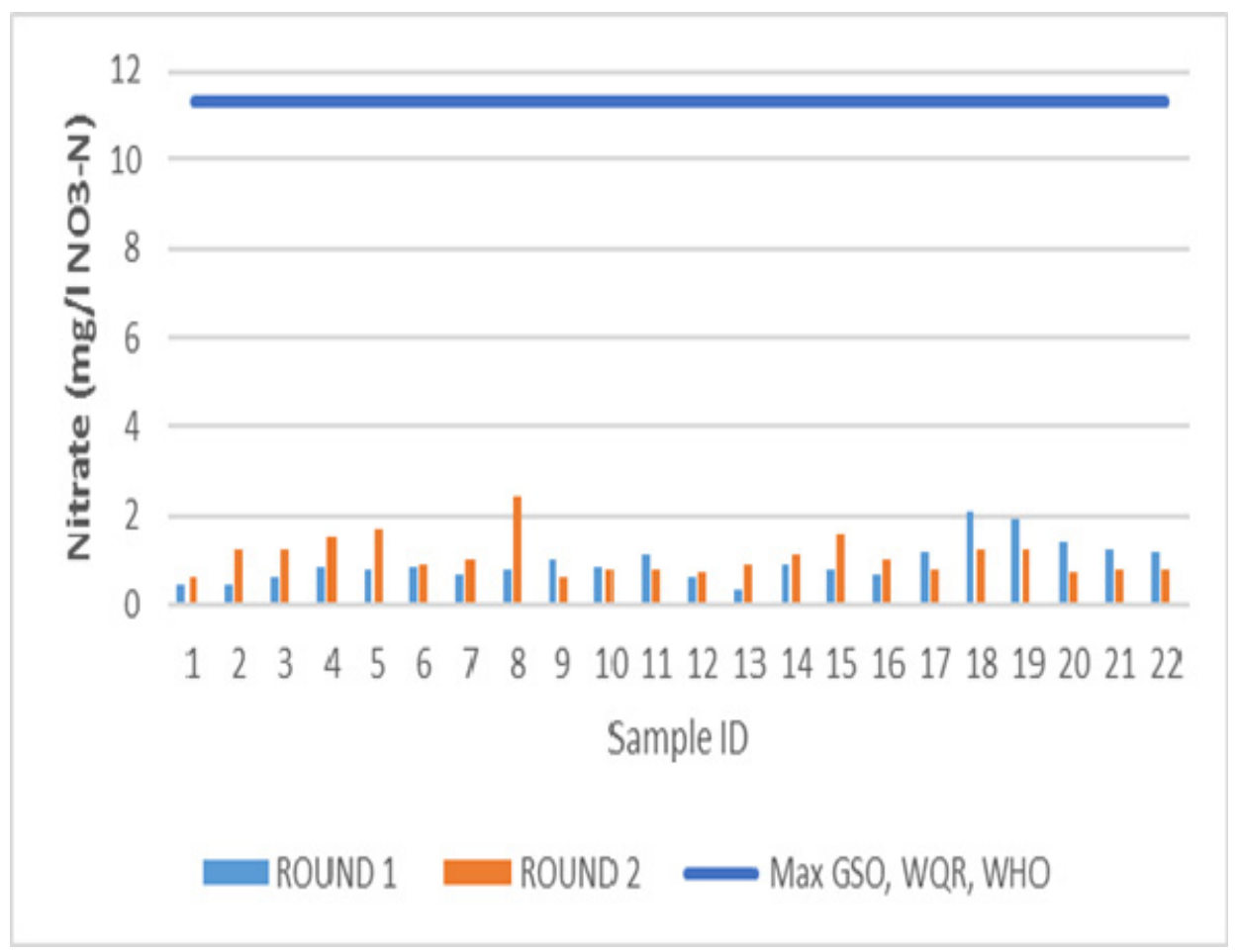

(f)

Figure 1: Continued. 


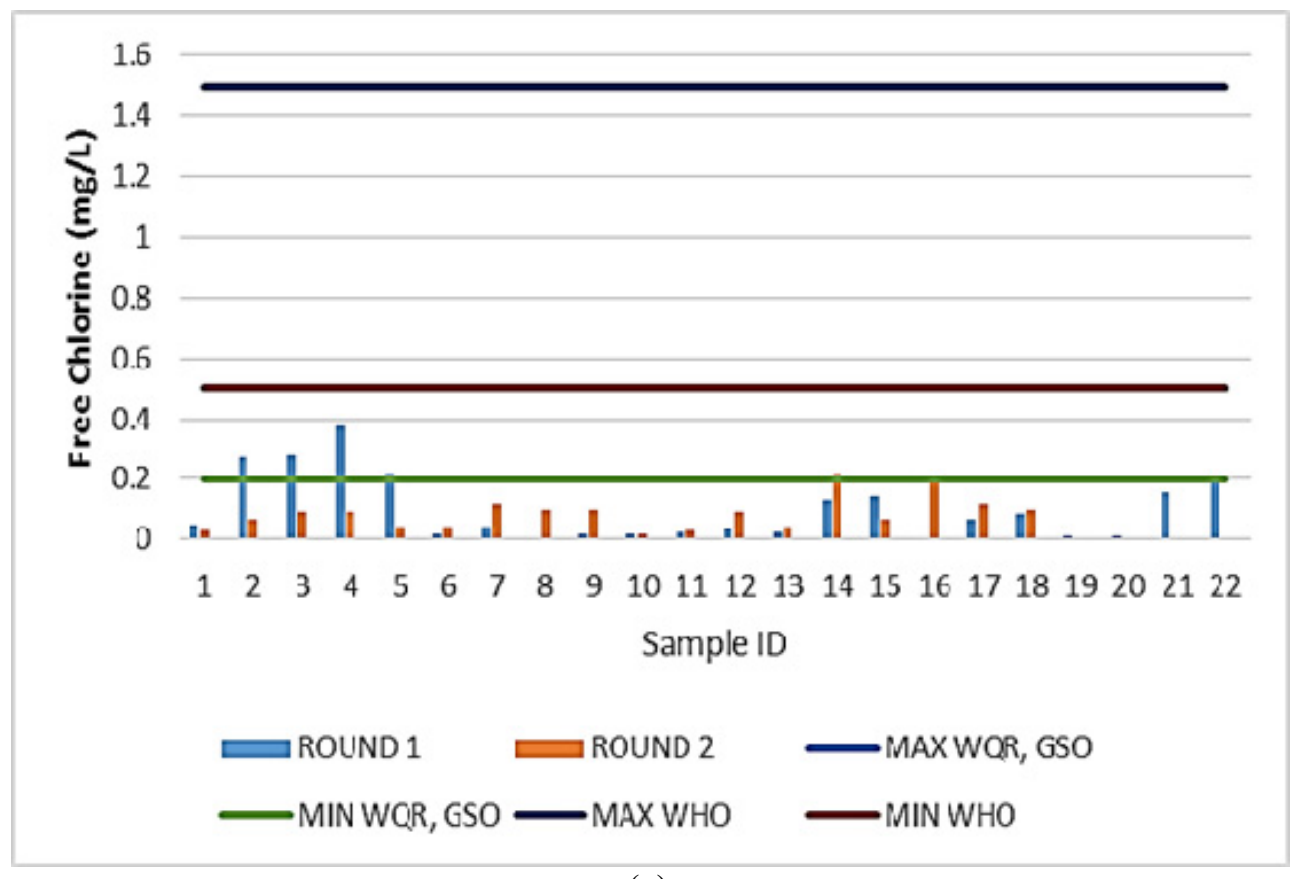

(g)

Figure 1: Continued.

requirements set by WHO, GSO, and WQR (Fig. 1(g)). Possible reasons can be chlorine volatilization especially in hot weather as well as chlorine reaction with chlorine consuming substances in the storage systems. Furthermore, the survey revealed that residents rarely clean and apply additional disinfectants to their water tanks.

Last, heavy metal analysis was also conducted on investigated waters. Iron, copper and zinc were $<0.1 \mathrm{mg} / \mathrm{L}$, thus below WHO, GSO, and WQR maximum acceptable levels for these metals.

\section{CONCLUSIONS}

Results demonstrate that the overall physico-chemical quality of water stored in household water storage tanks of stand-alone villas is acceptable except for operational parameters such as electrical conductivity and chlorides in 50\% of investigated samples; yet, such parameters do not pose major health hazards. However, free and total residual chlorine levels were below minimum requirements set by GSO and WQR in $93 \%$ of the samples, which may pose a risk of water re-contamination and may subject the consumers to possible water-related health effects. Microbiological quality of sampled water was acceptable in terms of total coliforms yet total bacterial counts and occasional presence of fungi and molds suggest poor hygienic conditions and highlight the need for tank cleaning, Variations in physico-chemical parameters were observed between the two rounds, possibly because of variations in supplied source water, water temperature, and installation of specific pollutant removal technologies by house owners. The study revealed that 
household water tanks owners rarely clean their tanks thus it is highly recommended to promote such measures and educate tank owners about the importance of regular tank cleaning and maintenance. As an intervention strategy, information related to basic steps and requirements for households' tanks design material and cleaning were distributed to tank owners and the public in the form of educational brochures to highlight the importance of safe water.

\section{ACKNOWLEDGEMENTS}

The authors express their gratitude to all water tank owners who have participated in this study. We also thank Ms Badriah Ebrahim for her efforts and assistance throughout the laboratory analyses.

\section{REFERENCES}

[1] World Health Organization (WHO), World Water Day Report 2017, World Health Organization: Geneva, Switzerland.

www.who.int/water_sanitation_health/takingcharge.html. Accessed on: 25 Jan. 2019.

[2] Akuffo, I., Cobbina, S.J., Alhassan, E.H. \& Nkoom, M., Assessment of the quality of water before and after storage in the Nyankpala community of the Tolon-Kumbungu District, Ghana. International Journal of Scientific and Technology Research, 2, pp. 221-227, 2013.

[3] Schafer, C., Impact of tank material on water quality in household water storage systems in Cochabamba, Bolivia. MSc thesis, University of South Florida, USA, 2010.

[4] Aish, M., Drinking water quality assessment of the middle governorate in the Gaza Strip, Palestine. Water Resources and Industry, 4, pp. 13-20, 2013.

[5] Ziadat, A.H., Impact of storage tanks on drinking water quality in Al-Karak Province-Jordan. Journal of Applied Sciences, 5, pp. 634-638, 2005.

[6] Graham, J.P. \& Van Derslice, J., The effectiveness of large household water storage tanks for protecting the quality of drinking water. Journal of Water and Health, 5, pp. 307-312, 2007.

[7] Sule, I.O., Agbabiaka, T.O. \& Akomolafe, A.V., Bacteriological quality of water stored exteriorly in storage tanks. Research Journal of Environmental Sciences, 5(6), pp. 603-610, 2011.

[8] Hani, F., مياه دبي المنتجة للمنازل صاحة للشرب 100\% و المشكلة في نظافة الخزانات القديمة www.albayan.ae/across-the-uae/2010-11-07-1.301692. Accessed on: 15 Dec. 2018.

[9] Amiri, A.H., Alkendi, R.R. \& Ahmed, Y.T., Quantification of bacteria in domestic water storage tanks in Sharjah. Journal of Water Resource and Ocean Science, 2, pp. 125-132, 2013.

[10] American Public Health Association (APHA), American Water Works Association (AWWA) \& Water Environment Federation (WEF), Standard Methods for the Examination of Water and Wastewater, 23rd ed., APHA Publication: Washington, DC, 2017.

[11] World Health Organization (WHO), Guidelines for Drinking-Water Quality: Fourth Edition Incorporating the First Addendum, 4th ed., World Health Organization: Geneva, Switzerland, 2017.

[12] GCC Standardization Organization (GSO), GSO 149/2014: Un-bottled drinking water. https://law.resource.org/pub/gso/ibr/gso.149.e.ds.2008.pdf. Accessed on: 15 Dec. 2018. 
132 Water and Society V

[13] The Water Quality Regulations (WQR), 4th ed., Regulation and Supervision Bureau: Abu Dhabi. http://rsb.gov.ae/. Accessed on: 15 Dec. 2018.

[14] Perlman, H., Hardness in Water, United States Geological Survey Water Science School: USA, 2016. 